\title{
Spontaninių subarachnoidinių hemoragijų literatūros apžvalga: gydymo ypatumai ir prevencija (II dalis)
}

\author{
J. Grigaite** \\ G. Rutkauskaité** \\ J. Ščerbak $* * *$ \\ L. Piliponis $* * * *$ \\ D. Jatužis* \\ J. Valaikiené*
}

*Vilniaus universitetas, Medicinos fakultetas, Neurologijos centras

**Respublikine Vilniaus

universitetiné ligonine

$* * *$ Vilniaus universiteto ligonine

Santaros klinikos,

Neurochirurgijos centras

$* * * *$ Lietuvos sveikatos mokslu universitetas, Medicinos fakultetas

\begin{abstract}
Santrauka. Efektyviausi plyšusių intrakranijinių aneurizmų gydymo būdai yra chirurginis klipsavimas ir endovaskulinis koilavimas. Taikant endovaskulinị gydymą, ankstyvų mirčių ir komplikacijų tikimybe yra mažesnè, ypač užpakalinės cirkuliacijos aneurizmų atveju, tačiau išlieka didelè aneurizmos rekanalizacijos ir plyšimo rizika, todėl indikuotinas ilgalaikis stebėjimas. Tuo tarpu klipsavimo ilgalaikè nauda yra labai svarbi jaunesnio amžiaus pacientams ir tam tikrais atvejais yra pirmo pasirinkimo gydymo metodas. Aneurizmos intervencinị gydymą rekomenduojama atlikti kiek galima anksčiau. Siekiant išvengti komplikacijų, visiems pacientams, patyrusiems spontaninę subarachnoidinę hemoragiją (SAH), rekomenduojama kasdien ar kas antrą dieną atlikti transkranijinę doplerografiją, o galvos kompiuterinę tomografiją, kompiuterinės tomografijos angiografiją (KTA), kompiuterinės tomografijos perfuziją ar skaitmeninę subtrakcinę angiografiją - hospitalizavimo dieną, 3-5 dieną ir 7-10 dieną. Vèlyvos smegenų išemijos prevencijai rekomenduojama skirti nimodipiną ir palaikyti euvolemiją, skiriant izotoninius kristaloidinius tirpalus. İvykus vazospazmui, rekomenduojama palaikyti euvoleminę indukuotą hipertenziją ir tam tikrais atvejais taikyti endovaskulini gydymą intraarteriniais vazodilatatoriais ar (ir) angioplastiką. Neplyšusių intrakranijinių aneurizmų gydymo taktikos pasirinkimas priklauso nuo natūralios ligos eigos ir plyšimo rizikos, kurią galima ịvertinti naudojantis ịvairiomis skalèmis. Parinkus stebejjimo taktiką, siūloma kartoti KTA ar magnetinio rezonanso tomografijos angiografiją (MRA) po 6-12 mẻnesių nuo aneurizmos nustatymo ir vertinti pokyčius dinamikoje. KTA ir MRA taip pat rekomenduojamos asmenims, turintiems 2 ar daugiau šeimos narių, kuriems nustatyta neplyšusių intrakranijinių aneurizmų ar diagnozuota SAH bei esant kitiems rizikos veiksniams. Pacientams, kuriems atsitiktinai aptikta besimptomė neplyšusi aneurizma, rekomenduojama mesti rūkyti, periodiškai matuoti kraujospūdị ir vengti sunkių svorių kèlimo.
\end{abstract}

Raktažodžiai: subarachnoidinė hemoragija, intrakranijinė aneurizma, endovaskulinis koilavimas, klipsavimas, vazospazmas, vẻlyvoji smegenų išemija.

\section{INTRAKRANIJINIŲ ANEURIZMŲ GYDYMAS}

Plyšusių intrakranijinių aneurizmų gydymo būdai

Pirminis SAH gydymo tikslas - atskirti aneurizmos maišą nuo intrakranijinès cirkuliacijos [1]. Efektyviausi intrakranijinių aneurizmų gydymo būdai - chirurginis klipsavimas ir endovaskulinis koilavimas. Gydymo taktikos pasirinki-

\author{
Adresas: \\ Julija Grigaite \\ Vilniaus universiteto Medicinos fakultetas \\ M. K. Čiurlionio g. 21, LT-03101 Vilnius \\ El.paštas julgrigaite@gmail.com
}

mas priklauso nuo paciento amžiaus, aneurizmos lokalizacijos, morfologijos, ryšio su greta esančiomis kraujagyslèmis. Sprendimą turi priimti multidisciplininè komanda, sudaryta iš neurochirurgų, intervencinių neuroradiologų ir skubios neurologijos specialistų [2].

Chirurginio ir endovaskulinio gydymo palyginimui yra atlikti du perspektyviniai randomizuoti klinikiniai tyrimai: ISAT (angl. International Subarachnoid Aneurysm Trial) ir BRAT (angl. Barrow Ruptured Aneurysm Trial) $[3,4]$. Tarptautinės ISAT studijos metu nustatyta, kad blogų išeičių (mirties arba neiggalumo, kai modifikuotos Rankino skalès (mRS) įvertis yra daugiau nei 2) dažnis yra statistiškai reikšmingai didesnis chirurginio klipsavimo grupejje, lyginant su endovaskulinio gydymo grupe po vienerių metų, atitinkamai 30,9 ir 23,5\%. Endovaskulinio gy-

(C) Neurologijos seminarai, 2021. Open Access. This article is distributed under the terms of the Creative Commons Attribution 4.0 International License CC-BY 4.0 (http://creativecommons.org/licenses/by/4.0/), which permits unrestricted use, distribution, and reproduction in any medium, provided you give appropriate credit to the original author(s) and the source, provide a link to the Creative Commons license, and indicate if changes were made. 
dymo grupejje nustatyta mažesnè epilepsijos rizika, bet didesnis aneurizmų rekanalizacijos ir plyšimo dažnis. Pagrindinis ISAT ịtraukimo kriterijus buvo paciento tinkamumas taikyti abu gydymo metodus, tačiau šį kriterijų atitiko tik $20 \%$ SAH patyrusių pacientų, todèl rezultatai neatspindi visos pacientų, patyrusių aneurizmos plyšimą, populiacijos [3]. İ kitą, SAH gydymo būdus lyginantị BRAT tyrimą buvo ịtraukti tik vieno centro netrauminès SAH atvejai ir pateikti ilgalaikio stebejjimo rezultatai po vienerių, trejų, šešerių ir 10 metų [4]. Statistiškai reikšmingas skirtumas tarp grupių buvo nustatytas tik po vienerių metų: blogų išeičių dažnis buvo didesnis tarp pacientų, kuriems buvo taikytas klipsavimas, lyginant su pacientais, kuriems buvo atliktas koilavimas (atitinkamai 33,7 ir 23,2 \%). Toks rezultatas buvo nulemtas užpakalinės cirkuliacijos aneurizmų blogesne prognoze klipsavimo grupeje. Tuo tarpu priekinės cirkuliacijos aneurizmų grupejje blogų išeičių dažnis tarp grupių statistiškai reikšmingai nesiskyrè. Svarbu paminèti, kad tik $62 \%$ koilavimo grupès pacientų buvo iš tikrujų gydyti endovaskuliniu būdu. Dažniausios perejjimo iš koilavimo ị klipsavimo grupę priežastys buvo intracerebrinė hematoma, mažas aneurizmos dydis, platus kaklas arba arterijos atsišakojimas aneurizmos srityje [4]. Atitinkamai agresyvesnis tokių aneurizmų gydymas endovaskuliniu būdu galètų pabloginti rezultatus koilavimo grupeje. Aneurizmos pilna obliteracija po klipsavimo buvo nustatyta $87 \%$ pacientų po operacijos ir pasiekè $93 \%$ po 10 metų stebėjimo. Koilavimo grupejje pilna obliteracija buvo nustatoma rečiau: iškart po gydymo - $52 \%$, o po 10 metų - tik $22 \%$ ligonių. Svarbu paminèti, kad pakartotinio gydymo dažnis buvo statistiškai reikšmingai didesnis koilavimo grupèje: per 10 stebejjimo metų $20 \%$ koiluotų aneurizmų buvo gydomos pakartotinai, kai klipsavimo grupejje pakartotinio gydymo dažnis sudare $<1 \%$. Be to, endovaskulinio gydymo grupeje įvyko du mirtini aneurizmų plyšimai, o klipsavimo grupejje pooperacinių plyšimų nenustatyta [4]. Koiluotų aneurizmų išliekančią ilgalaikę plyšimo riziką ịrodo ir neplyšusių aneurizmų stebejjimo tyrimas: po 8,5 metų aneurizmos plyšimas įvyko 3,4 \% stebėtų, konservatyviai gydytų pacientų, 2,8\% endovaskuliniu būdu gydytų pacientų ir $0,5 \%$ chirurginiu klipsavimu gydytų pacientu [5]. Remiantis kitos studijos rezultatais, per 18 metų 127 pacientams $(22,1 \%)$, kuriems buvo taikytas endovaskulinis aneurizmų gydymas, stebèta rekanalizacija, reikalaujanti papildomo gydymo. 68,5\% rekanalizavusių ir didėjančiuc aneurizmų buvo visiškai obliteruotos po endovaskulinio gydymo ir rekanalizacija atsirado stebejjimo metu, o gydytų aneurizmų plyšimų dažnis siekẻ $15 \%$ per 18 metų stebėjimo laikotarpi [6].

Minèti rezultatai įrodo, kad, taikant endovaskulinị gydymą, ankstyvų blogų rezultatų tikimybè yra mažesnè, ypač užpakalinès cirkuliacijos aneurizmų atveju. Visgi, taikant pastaraji gydymo būdą, išlieka didelè aneurizmos rekanalizacijos ir plyšimo rizika, indikuotinas ilgalaikis stebėjimas. Tuo tarpu klipsavimo ilgalaikè nauda yra labai svarbi jaunesnio mažiaus pacientams ir tam tikrais atvejais yra pirmo pasirinkimo gydymo metodas.

\section{Medikamentinis gydymas po îvykusios subarachnoidinès hemoragijos}

Plyšusios intrakranijinės aneurizmos intervencinis gydymas turi būti taikomas kaip įmanoma greičiau (I klasės, $\mathrm{B}$ lygio rekomendacija), siekiant išvengti pakartotinio kraujavimo. Geriausiai tai atlikti neviršijant $24-72$ valandų (kai kurie ekspertų centrai nurodo vidutinị 7 valandų nuo hospitalizavimo iki aneurizmos obliteracijos laiką). Pacientams, kuriems neįmanoma skubiai atlikti aneurizmos obliteracijos, nesant kontraindikacijų, trumpą laiką (mažiau nei 72 val.) gali būti skiriamos antifibrinolizinès medžiagos (traneksaminė ar aminokaproinė rūgštis) [2].

Didėjant naujų geriamųjų antikoaguliantų (NGAK) vartojimui, reikšmingu iššūkiu tampa juos vartojančių ir SAH patyrusių pacientų gydymas. Idarucizumabas pirmasis, 2015 m. FDA (angl. Food and Drug Administration), vèliau ir EMA (angl. European Medicines Agency) patvirtintas, NGAK grịžtamojo veikimo antagonistas - visiškai humanizuotas, monokloninis antikūnas, specifinis trombino inhibitoriaus dabigatrano antidotas. Šis vaistas gali būti vartojamas esant skubių chirurginių intervencijų būtinybei, pavyzdžiui, įvykus SAH [7]. Be to, 2014 metų AHA/ACC/HRS prieširdžių virpejjimo gydymo gairès $2019 \mathrm{~m}$. taip pat papildytos rekomendacija skirti idarucizumabą pacientams, vartojantiems dabigatraną ir patyrusiems gyvybei grèsmingą kraujavimą ar esant skubių intervencijų poreikiui (I klasès rekomendacija) [8]. Idarucizumabo veikimo efektyvumą įrodo multicentrinè perspektyvinė kohortinè studija RE-VERSE AD (angl. Reversal Effects of Idarucizumab on Active Dabigatran), kurios rezultatai parodè, kad idarucizumabą paskyrus pacientams, anksčiau vartojusiems dabigatraną ir patyrusiems nekontroliuojamą, gyvybei grèsmingą kraujavimą, praskiesto trombino laikas (dTT) pasiekè normos ribas $98 \%$ tiriamųjų, o grupèje pacientų, kuriems buvo būtina invazinė procedūra ar chirurginė intervencija per 8 val., - $93 \%$ atvejų [9]. Pacientams, kuriems šis vaistas buvo paskirtas per 24 valandas nuo kraujavimo pradžios, per vidutiniškai 2,5 valandos kraujavimas buvo sukontroliuotas [9]. Rekomenduojama idarucizumabo dozè - 2,5 g intravenine infuzija 2 kartus su ne ilgesne nei 15 minučiu pertrauka [10]. Taip pat yra sukurta ir kuriama vis nauju NGAK antagonistų: andeksanetas alfa (Xa faktoriaus antagonistas), 2018 m. registruotas FDA kaip rivaroksabano ir apiksabano antidotas, ciraparantagas (universalus antidotas, tiesiogiai veikiantis tiek trombino, tiek Xa faktoriaus inhibitorius bei nefrakcionuotą ir mažos molekulinės masės hepariną), dar nepatvirtintas FDA ir EMA [11-13]. Nors šiuo metu yra sukaupta nedaug duomenų apie NGAK vartojančius pacientus, patyrusius netrauminę $\mathrm{SAH}$, rekomenduojama laikytis tų pačių gydymo grịžtamaisiais NGAK antagonistais rekomendacijų, kaip ir įvykus intrakranijiniam kraujavimui [13]. 


\section{Neplyšusių intrakranijinių aneurizmų stebėjimas ir gydymas}

Atliekant vaizdinius tyrimus dèl SAH ar kitų indikacijų, gali būti aptinkama ir neplyšusių aneurizmų, vadinamųjų incidentalomų [14]. Sprendžiant neplyšusių aneurizmų tolimesnio gydymo taktiką, svarbu ịvertinti natūralią ligos eigą ir plyšimo riziką. Remiantis tyrimais, nagrinejjusiais neplyšusių aneurizmų natūralią eigą, nustatyta, kad mažų aneurizmų plyšimo rizika nėra didelè. Perspektyvinėje tarptautineje ISUIA (angl. International Study of Unruptured Intracranial Aneurysms) studijoje nustatyta, kad priekinès cirkuliacijos $<7 \mathrm{~mm}$ dydžio aneurizmų plyšimo per 5 metus nebuvo [15]. O Japonijoje atliktos studijos rezultatai parodè, kad mažesnių nei $5 \mathrm{~mm}$ aneurizmų plyšimo dažnis yra $0,36 \%$ per metus [16]. Retrospektyviai analizuojant plyšusių aneurizmų dydị, nustatyta, kad dauguma $(85,6 \%)$ plyšusių aneurizmų buvo $<10 \mathrm{~mm}$ skersmens [17]. Rezultatų prieštaravimą paaiškina tai, kad ị pastaraji tyrimą buvo įtrauktos aneurizmos, kurioms, gydytojo sprendimu, buvo pasirinkta stebėjimo taktika. Nemaža dalis aneurizmų, kurios tyrimo metu tapo simptominès arba padidejo, buvo gydomos, todèl minèti rezultatai neatspindi visų atsitiktinai rastų aneurizmų natūralios eigos ir plyšimo tikimybès [18].

Klinikiniam sprendimui priimti gali būti naudojamos skalès, vertinančios plyšimo riziką ir indikacijas gydymui. Plyšimo rizikai įvertinti naudojama PHASES (angl. Population, Hypertension, Age, Size of aneurysm, Earlier SAH from another aneurysm, Site of aneurysm) skalè, ị kurią itraukti paciento ir aneurizmos veiksniai, didinantys plyšimo riziką [19]. Sprendžiant neplyšusios aneurizmos tolimesnio gydymo taktiką, taip pat naudinga vertinti UIATS (angl. Unrupted Intracranial Aneurysm Treatment Score) skalę, kuri sukurta remiantis tarptautinių ekspertų sutarimu. Svarbu paminėti, kad ị šią skalę ịtraukti ne tik paciento ir aneurizmos rodikliai, bet ir su gydymu susiję rizikos veiksniai [20].

Taikant chirurginị neplyšusių aneurizmų gydymą, sergamumas siekia $4 \%$, o mirštamumas - $1 \%$. Tuo tarpu po endovaskulinio gydymo kombinuotas sergamumo ir mirštamumo santykis yra lygus 8-9 \% [14]. Nors ankstesnèse studijose buvo teigiama, kad komplikacijų rizika mažèja su laiku po endovaskulinio ir chirurginio gydymo, $2018 \mathrm{~m}$. atlikta sisteminė apžvalga ir metaanalizė įrodè, kad rizika mažèja su laiku tik taikant neurochirurgini gydymą [21].

Pasirinkus stebejjimo taktiką, periodiškai turi būti atliekama galvos kompiuterinès tomografijos angiografija (KTA) ar magnetinio rezonanso tomografijos angiografija (MRA) ir vertinama aneurizmos didejimo dinamika. Pastarieji tyrimai taip pat rekomenduojami pacientams, kurių 2 ar daugiau šeimos narių turi neplyšusių intrakranijinių aneurizmų ar patyrè SAH, ypač kartu esant ir kitiems rizikos veiksniams, tokiems kaip arterinė hipertenzija, rūkymas, moteriška lytis, autosominė dominantinė policistinių inkstų liga ir kita [22]. Kadangi nėra tikslių gairių, nurodančių, kokiu dažniu reikètų atlikti vaizdinius tyrimus, rekomenduojama pirmą kartą tyrimą kartoti per
6-12 mėnesių po aneurizmos aptikimo, o vẻliau spręsti individualiai. Vienos studijos rezultatai parodè, kad aneurizmų augimo greitis yra tiesiogiai proporcingas jų dydžiui: per 4 metus padidejja 6,9\%, kai aneurizmos dydis yra mažesnis nei $8 \mathrm{~mm} ; 25 \%$, kai aneurizmos dydis 8-12 mm, ir $83 \%$, kai aneurizmos dydis viršija $12 \mathrm{~mm}$. Todèl, esant didesnio skersmens aneurizmai, vaizdiniai tyrimai gali būti kartojami dažniau [14]. Svarbu paminėti, kad pacientams, atsitiktinai aptikus neplyšusias aneurizmas, nèra būtina taikyti ịprasto fizinio krūvio, chirurginiu intervencijų ar vartojamų vaistų, įskaitant antikoaguliantus, apribojimų. Viename didelès apimties kohortiniame tyrime pateikiama išvada, kad aspirino vartojimas gali netgi sumažinti plyšimo riziką, tačiau visgi reikia daugiau perspektyvinių tyrimų, kad būtų galima skirti šị vaistą plyšimo prevencijai [14]. Pacientams su neplyšusiomis aneurizmomis gali būti rekomenduojama mesti rūkyti, periodiškai matuoti kraujospūdi, vengti sunkių svorių kèlimo [14]. Viena atlikta studija teigia, kad aneurizmų plyšimo dažnis nèra didesnis nėščiųjų grupejje, tačiau pastebèta, kad Cezario pjūvio operacijos pasitaiko dažniau neplyšusias aneurizmas turinčių moterų grupèje nei neturinčiųjų aneurizmų [23].

\section{KOMPLIKACIJŲ GYDYMAS IR PREVENCIJA}

Visiems pacientams, patyrusiems spontaninę SAH, svarbu atlikti vaizdinius tyrimus dinamikoje, siekiant identifikuoti galimą sumažèjusią galvos smegenų perfuziją, vazospazmą. Rekomenduojama atlikti transkranijinę doplerografiją kasdien ar kas antrą dieną, galvos KT, KTA, kompiuterinės tomografijos perfuziją (KTP) ar skaitmeninę subtrakcinę angiografiją (SSA) hospitalizavimo dieną, 3-5 dieną ir 7-10 dieną [24]. Kadangi vėlyvoji smegenų išemija yra viena grèsmingiausių ir dažniausių komplikacijų, atliekama nemažai tyrimų, siekiant nustatyti efektyvias priemones ankstyvai šios būklès diagnostikai, gydymui ir prevencijai. Šiuo metu ypač pabrèžiama uždegiminių rodiklių reikšmė ir manoma, kad tai gali praversti vertinant vèlyvos smegenų išemijos grèsmę [24]. IL-1, IL-6 ir TNF- $\alpha$ padidejimas likvore yra susijęs su hemodinaminiais pokyčiais transkranijinejje doplerografijoje ir vazospazmu, o izoliuotas IL-6 padidèjimas laikomas ankstyvu vėlyvosios smegenų išemijos požymiu ir siejamas su prastesnèmis išeitimis [25]. Tiesa, būtina atlikti daugiau kontroliuojamų, perspektyvinių, multicentrinių tyrimų, kad būtų galima tiksliau vertinti uždegiminių rodiklių klinikinę reikšmę.

Pacientai, patyrę spontaninę SAH, yra grupuojami i mažos rizikos (1-2 WFNS (angl. World Federation of Neurological Surgeons Grading System for Subarachnoid Hemorrhage) skalès balai ir mažiau nei 3 modifikuotos Fišerio skalès balai), didelès rizikos (1-3 WFNS skalès balai ir 3 modifikuotos Fišerio skalès balai) ir didelès rizikos su prasta neurologine būkle (apsunkintas fizinis ištyrimas dèl sedacijos, 3-5 WFNS skalès balai, 4 modifikuotos Fišerio 
skalès balai). Pastarajai grupei priklausantys pacientai turi būti papildomai monitoruojami, atliekant EEG, stebint galvos smegenų oksigenaciją ir kraujotaką. Žemos rizikos grupès pacientai, esant stabiliai būklei, nesant vazospazmo ir hipoperfuzijos, gali būti perkelti iš intensyviosios terapijos skyriaus ì žemesnio lygio priežiūrą po 5 dienų nuo simptomų pradžios, didelès rizikos - po 7 dienų, o didelès rizikos su prasta neurologine būkle - tik po 14 dienų [2].

Daugiausia nagrinètos, efektyviausios ir prieinamiausios vèlyvosios smegenų išemijos prevencijos priemonès kalcio kanalų blokatoriai ir tinkamas intravaskulinio tūrio palaikymas [26-28]. Anksčiau vėlyvos smegenų išemijos profilaktikai buvo rekomenduojama hipervoleminè terapija, tačiau ši strategija nepasiteisino ir buvo susijusi su didesne kardiopulmoninių komplikacijų rizika. Todėl šiuo metu po SAH rekomenduojama palaikyti euvolemiją, naudojant izotoninius kristaloidinius tirpalus [26, 27]. Nimodipinas (kalcio kanalų blokatorius) yra vienintelis vaistas, kurio efektyvumą SAH atveju įrodė randomizuoti placebo kontroliuojami tyrimai [29]. Šis vaistas pasižymi neuroprotekciniu poveikiu, tačiau vazospazmo dažnio nemažina. Rekomenduojama enteriškai skirti 60 mg nimodipino kas 4 valandas 21 dieną. Dažniausiai stebimas nepageidaujamas poveikis - konstipacija ir hipotenzija [2]. Pastarosios nepageidaujamos reakcijos dažnai kelia dilemą klinikinėje praktikoje: ar išvis nutraukti, ar mažinti skiriamą dozę, ar papildomai skirti vazopresoriu [29]. Konferencijoje „Neurokritinès priežiūros organizacijos multidisciplininis konsensusas" (angl. The Neurocritical Care Society's Multidisciplinary Consensus) buvo teigiama, kad, esant hipotenzijai, nimodipinas turi būti skiriamas dažniau ir mažesnėmis dozėmis, pavyzdžiui, $30 \mathrm{mg}$ kas 2 val. Toks dozavimas nebuvo susijęs su prastesnėmis išeitimis ar mažesniu efektyvumu [27, 29]. Be to, $118 \mathrm{SAH}$ patyrusių pacientų retrospektyvinè analizė parodè, kad gydytojo nurodymų laikymasis, t. y. teisingas nurodytų nimodipino dozių vartojimas ir režimo laikymasis, buvo susijęs su trumpesne hospitalizavimo, buvimo intensyviosios terapijos skyriuje trukme bei geresnèmis klinikinėmis išeitimis (GOS (angl. Glasgow Outcome Scale) įvertis >3) išleidimo iš ligoninès metu, lyginant su pacientais, kurie praleido vieną ar daugiau nimodipino dozių. Taip pat buvo pastebèta, kad visi pacientai, mirę po ịvykusios $\mathrm{SAH}$, nevartojo nimodipino pilnu, tinkamu režimu [29].

Magnis, kuris yra nekonkurencinis kalcio antagonistas, skiriamas po SAH, kaip ir nimodipinas pasižymi vazodilataciniu ir neuroprotekciniu poveikiu [30]. Šis preparatas, ikiklinikinių ir II fazès klinikinių tyrimų duomenimis, buvo efektyvus, tačiau, atlikus paskutinị multicentrini III fazès randomizuotą, placebo kontroliuojamą tyrimą, vertinantị klinikinị intraveniškai skirto magnio po SAH efektyvumą, akivaizdžios šio vaisto skyrimo naudos nenustatyta [31]. Todèl magni verta skirti ne vazospazmo, o magnio stokos, kuri dažnai pasitaiko SAH patyrusių pacientų grupeje, prevencijai [29]. Taip pat buvo manoma, kad statinai, netiesiogiai didindami endogeninio azoto oksido kiekị, gali būti efektyvūs vazospazmo prevencijai, tačiau paskutinysis STASH (angl. Simvastatin in
Aneurysmal Subarachnoid Hemorrhage) tyrimas neirrodè simvastatino skyrimo naudos [32]. Analogiškai buvo atliekami tyrimai su selektyviu endotelino receptorių antagonistu klazosentanu, kuris nežymiai sumažino vazospazmo dažnị, tačiau kartu buvo susijęs su dideliu nepageidaujamų reakcijų (plaučių edema, hipotenzija ir kt.) dažniu [33, 34]. Taip pat šiuo metu vykdomi ir kitų farmakologinių medžiagų, galimai turinčių poveikị vèlyvos smegenų išemijos prevencijai, tyrimai: 21-aminosteroido tirilizado, inhibuojančio lipidų peroksidaciją, kuri, manoma, yra vienas iš vazospazmą lemiančių veiksnių; eritropoetino, kuris veikia neuroprotekciškai, palaikydamas normalią kraujagyslių autoreguliaciją; peroralinio antidiabetinio vaisto gliburido, kuris itin mažina neurouždegiminių žymenų kiekį ir veikia neuroprotekciškai [1].

İrodžius uždegiminių procesų reikšmę SAH patogenezėje, buvo manoma, kad uždegimą slopinančių vaistų paskyrimas taip pat gali užkirsti kelią išeminėms komplikacijoms atsirasti. Vienos retrospektyvinès kohortinės studijos rezultatai parode, kad deksametazono skyrimas bendrai sumažino nepalankių išeičių dažnị SAH pacientams, tačiau efektyvumo vėlyvajai smegenų išemijai šis vaistas neturejjo. Be to, gliukokortikoidų vartojimas yra susijęs su didesne infekcijų rizika, todèl rutiniškai jo skirti nerekomenduojama $[24,35]$. Nassiri ir kt. taip pat atliko studiją, nagrinëjusią $178 \mathrm{SAH}$ patyrusius pacientus, iš kurių 89 buvo skiriama nesteroidinių vaistų nuo uždegimo (NVNU) [36]. Šios studijos rezultatai parodè, kad NVNU vartojimas buvo susijęs su mažesniu mirtingumu ir trumpesne hospitalizacijos trukme, tačiau nebuvo stebima geresnių funkcinių išeičių, vèlyvos smegenų išemijos, vazospazmo dažnio sumažejimo, todèl gydymas NVNU SAH komplikacijų prevencijai nerekomenduojamas.

Viena perspektyvinė studija, nagrinėjusi SAH patyrusius pacientus, monitoruotus transkranijine doplerografija, pastebejo, kad mikroemboliniai signalai buvo dažnesni pacientams, turintiems vazospazmą $[37,38]$. Tai grindžiama tuo, kad uždegiminiai procesai, darantys ịtaką vazospazmo atsiradimui, kartu yra susiję su trombocitų adhezija, krešejimo kaskados aktyvacija ir mikrotrombų susiformavimu [39]. Anksčiau minètas profilaktikai plačiai vartojamas nimodipinas taip pat pasižymi ir fibrinoliziniu aktyvumu, taip slopindamas mikrotrombų formavimąsi ir kartu apsaugodamas nuo išeminių komplikacijų atsiradimo [40]. Nors krešejjimo mechanizmų reikšmė vazospazmo patogenezèje yra įrodyta, tačiau 7 randomizuotų klinikinių tyrimu metaanalizė neparodė antitrombocitinių vaistu efektyvumo SAH metu [41]. Šiuo metu nèra atlikta pakankamai tyrimų, nagrinėjančių gydymo metodus, tiesiogiai veikiančius neurouždegiminius, krešèjimo procesus, todèl būtina išsamesnè šios srities analizė [24].

Kaip anksčiau minėta, vietoj tradiciškai žinomos $3 \mathrm{H}$ trigubos vazospazmo gydymo strategijos šiuo metu rekomenduojama euvoleminė indukuota hipertenzija (sistolinis kraujo spaudimas $<160 \mathrm{mmHg}$ ), vengiant hipervolemijos, analogiškai kaip ir vazospazmo prevencijai [26, 42]. Arterinè hipertenzija palaikoma bent 72 val. ar iki tol, kol būklè tampa stabili. Paprastai skiriama 1-2 litrai 0,9\% 
$\mathrm{NaCl}$ boliusu ir norepinefrinas ar kiti vazopresoriai. Svarbu, kad kraujospūdžio didejjimas būtų indukuojamas laipsniškai ir, sistoliniam kraujo spaudimui didejjant kas $10 \mathrm{mmHg}$, būtų vertinama neurologinè būklè. Jei neurologinis deficitas persistuoja, rekomenduojama atlikti $\mathrm{KT}$, KTA, KTP ar SSA ir, esant vazospazmui, taikyti endovaskulinę terapiją intraarteriniais vazodilatatoriais ar (ir) angioplastiką. Esant radiologiniams pokyčiams, tačiau nestebint neurologinės būklès blogejjimo, endovaskulinė terapija nerekomenduojama, nes šiuo atveju ji yra susijusi su blogesnèmis išeitimis [26, 27].

İtariant simptominę obstrukcinę hidrocefaliją, būtina atlikti galvos KT ir ịvesti išorinị ventrikulinị dreną [2].

Kardiopulmoninių komplikacijų prevencijai rekomenduojama periodiškai vertinti širdies fermentų koncentraciją, atlikti EKG, echokardioskopiją [2, 27].

Vaistų nuo epilepsijos (VNE) skyrimas traukulių profilaktikai SAH patyrusiems pacientams anksčiau buvo iprasta praktika. Visgi pastebėta, kad šių vaistų, ypač fenitoino, skyrimas yra susijęs su blogesnèmis klinikinėmis išeitimis bei dažnesnèmis nepageidaujamomis reakcijomis i vaistą. Todėl profilaktinis fenitoino skyrimas nerekomenduojamas, o esant indikacijoms reikètų rinktis kitus VNE ir skirti ne ilgiau kaip 3-7 dienas. Kadangi subklinikinių traukulių pasireiškimas yra dažnesnis tarp sunkios būklès, masyvias SAH patyrusių pacientų, jiems rekomenduojamas tęstinis EEG atlikimas [2, 26, 27].

\section{IŠVADOS}

1. Pacientams, patyrusiems SAH dèl intrakranijinès aneurizmos plyšimo, intervencinį jos gydymą (klipsavimą, endovaskulinị koilavimą) rekomenduojama pradèti kiek galima anksčiau (I klasės, B lygio rekomendacija). Jeigu greitu metu to atlikti neịmanoma, trumpiau nei 72 val. gali būti skiriamos antifibrinolizinès medžiagos (traneksaminė ar aminokaproinė rūgštis), o vartojantiems dabigatraną - grịžtamojo veikimo antagonistas idarucizumabas.

2. Pacientams, kuriems atsitiktinai randamos aneurizmos galvos smegenyse, pasirinkus stebejjimo taktiką siūloma periodiškai kartoti KTA ar MRA ir vertinti pokyčius dinamikoje. Rekomenduojama pirmą kartą tyrimą kartoti po 6-12 mènesių diagnozavus aneurizmą, o vèliau spręsti individualiai.

3. Pacientams, kuriems atsitiktinai aptikta neplyšusi aneurizma, netaikomi ịprasto fizinio krūvio, chirurginių intervencijų ar vartojamų vaistų apribojimai, tačiau rekomenduojama mesti rūkyti, periodiškai matuoti kraujospūdị, vengti sunkių svorių kèlimo.

4. SAH pacientams komplikacijų prevencijai rekomenduojamas atidus neurologinės būklès stebėjimas, reguliarus transkranijinès doplerografijos atlikimas, euvolemijos palaikymas naudojant izotoninius kristaloidinius tirpalus, nimodipino $60 \mathrm{mg}$ vartojimas 6 kartus per parą 21 dieną, EKG, širdies žymenų, echokardioskopijos atlikimas.
5. Vazospazmui gydyti rekomenduojama euvoleminè indukuota hipertenzija (sistoliniam kraujo spaudimui neviršijant $160 \mathrm{mmHg}$ ). Jei neurologinis deficitas persistuoja, esant vazospazmo požymiams vaizdiniuose tyrimuose, rekomenduojama taikyti endovaskulinę terapiją intraarteriniais vazodilatatoriais ar (ir) angioplastiką.

6. Uždegimą slopinančių vaistų, tokių kaip gliukokortikoidų ar nesteroidinių vaistų nuo uždegimo, bei vaistų nuo epilepsijos skyrimas komplikacijų prevencijai nerekomenduojamas.

\section{Literatūra}

1. Grasso G, Alafaci C, Loch Macdonald R. Management of aneurysmal subarachnoid hemorrhage: state of the art and future perspectives. Surg Neurol Int 2017; 8(1): 11. https://doi.org/10.4103/2152-7806.198738

2. Suarez JI. Diagnosis and management of subarachnoid hemorrhage. Continuum (Minneap Minn) 2015; 21: 1263-87. https://doi.org/10.1212/CON.0000000000000217

3. Molyneux AJ, Kerr RS, Yu LM, et al. International Subarachnoid Aneurysm Trial (ISAT) of neurosurgical clipping versus endovascular coiling in 2143 patients with ruptured intracranial aneurysms: a randomised comparison of effects on survival, dependency, seizures, rebleeding, subgroups, and aneurysm occlusion. Lancet 2005; 366(9488): 809-17. https://doi.org/10.1016/S01406736(05)67214-5

4. Spetzler RF, Zabramski JM, McDougall CG, et al. Ten-year analysis of saccular aneurysms in the Barrow Ruptured Aneurysm Trial. J Neurosurg 2018; 128(1): 120-5. https://doi.org/10.3171/2016.9.JNS161301

5. Torner J, Piepgras D, Meissner I, et al. Long-term follow-up in patients surgically treated for an unruptured intracranial aneurysm. J Neurosurg 2008; 108: A866.

6. Dorfer C, Gruber A, Standhardt H, et al. Management of residual and recurrent aneurysms after initial endovascular treatment. Neurosurgery 2012; 70: 537-54. https://doi.org/ 10.1227/NEU.0b013e3182350da5

7. Burness CB. Idarucizumab: first global approval. Drugs 2015; 75(18): 2155-61. https://doi.org/10.1007/s40265015-0508-5

8. January CT, Wann LS, Calkins H, et al. Correction to: 2019 AHA/ACC/HRS focused update of the 2014 AHA/ACC/ HRS guideline for the management of patients with atrial fibrillation: a report of the American College of Cardiology/ American Heart Association Task Force on Clinical Practice Guidelines and the Heart Rhythm Society. Circulation 2019; 140(2): e125-51. https://doi.org/10.1161/CIR. 0000000000000665

9. Pollack CV, Reilly PA, Bernstein R, et al. Design and rationale for RE-VERSE AD: a phase 3 study of idarucizumab, a specific reversal agent for dabigatran. Thromb Haemost 2015; 114(1): 198-205. https://doi.org/10.1160/ TH15-03-0192

10. Buchheit J, Reddy P, Connors JM. Idarucizumab (Praxbind) formulary review. Crit Pathw Cardiol 2016; 15(3): 77-81. https://doi.org/10.1097/HPC.0000000000000076

11. Connolly SJ, Gibson CM, Crowther M. Andexanet alfa for factor Xa inhibitor reversal. N Engl J Med 2016; 375(25): 2499-500. https://doi.org/10.1056/ NEJMc1613270 
12. Ansell JE. Universal, class-specific and drug-specific reversal agents for the new oral anticoagulants. J Thromb Thrombolysis 2016; 41(2): 248-52. https://doi.org/10.1007/ s11239-015-1288-1

13. Gerner ST, Huttner HB. Patients on NOACs in the emergency room. Curr Neurol Neurosci Rep 2019; 19(7): 40. https://doi.org/10.1007/s11910-019-0954-7

14. Flemming KD, Lanzino G. Management of unruptured intracranial aneurysms and cerebrovascular malformations. Continuum (Minneap Minn) 2017; 23(1): 181-210. https://doi.org/10.1212/CON.0000000000000418

15. Wiebers DO, Whisnant JP, Huston J, et al. Unruptured intracranial aneurysms: natural history, clinical outcome, and risks of surgical and endovascular treatment. Lancet 2003; 362(9378): 103-10. https://doi.org/10.1016/ S0140-6736(03)13860-3

16. Morita A, Kirino T, Hashi K, et al. The natural course of unruptured cerebral aneurysms in a Japanese cohort. N Engl J Med 2012; 366(26): 2474-82. https://doi.org/10.1056/ NEJMoa1113260

17. Forget TR, Benitez R, Veznedaroglu E, et al. A review of size and location of ruptured intracranial aneurysms. Neurosurgery $2001 ; 49(6)$ : 1322-6. https://doi.org/10.1097/ 00006123-200112000-00006

18. Marbacher S, Diepers M, Kahles T, et al. Interdisciplinary decision-making and treatment of intracranial aneurysms in the era of complementary microsurgical and endovascular techniques. Swiss Med Wkly 2016; 146: w 14372. https://doi.org/10.4414/smw.2016.14372

19. Backes D, Vergouwen MD, Tiel Groenestege AT, et al. Phases score for prediction of intracranial aneurysm growth. Stroke 2015; 46(5): 1221-6. https://doi.org/10.1161/ STROKEAHA.114.008198

20. Etminan N, Brown RD, Beseoglu K, et al. The unruptured intracranial aneurysm treatment score: a multidisciplinary consensus. Neurology 2015; 85(10): 881-9. https://doi.org/ 10.1212/WNL.0000000000001891

21. Algra AM, Lindgren A, Vergouwen MDI, et al. Procedural clinical complications, case-fatality risks, and risk factors in endovascular and neurosurgical treatment of unruptured intracranial aneurysms: a systematic review and meta-analysis. JAMA Neurol 2019; 76(3): 282-93. https://doi.org/ 10.1001/jamaneurol.2018.4165

22. Thompson BG, Brown RD, Amin-Hanjani S, et al. Guidelines for the management of patients with unruptured intracranial aneurysms: a guideline for healthcare professionals from the American Heart Association/American Stroke Association. Stroke 2015; 46(8): 2368-400. https://doi.org/10.1161/STR.0000000000000070

23. Kim YW, Neal D, Hoh BL. Cerebral aneurysms in pregnancy and delivery: pregnancy and delivery do not increase the risk of aneurysm rupture. Neurosurgery 2013; 72(2): 143-9. https://doi.org/10.1227/NEU.0b013e3182796af9

24. de Oliveira Manoel AL, Loch Macdonald R. Neuroinflammation as a target for intervention in subarachnoid hemorrhage. Front Neurol 2018; 9: 292. https://doi.org/10.3389/ fneur.2018.00292

25. Muroi C, Hugelshofer M, Seule M, et al. Correlation among systemic inflammatory parameter, occurrence of delayed neurological deficits, and outcome after aneurysmal subarachnoid hemorrhage. Neurosurgery 2013; 72(3): 367-75. https://doi.org/10.1227/NEU. ob013e31828048ce
26. Connolly ES, Rabinstein AA, Carhuapoma JR, et al. Guidelines for the management of aneurysmal subarachnoid hemorrhage: a guideline for healthcare professionals from the American Heart Association/American Stroke Association. Stroke 2012; 43(6): 1711-37. https://doi.org/10.1161/ STR.0b013e3182587839

27. Diringer MN, Bleck TP, Claude Hemphill J, et al. Critical care management of patients following aneurysmal subarachnoid hemorrhage: recommendations from the Neurocritical care society's multidisciplinary consensus conference. Neurocrit Care 2011; 15(2): 211-40. https://doi.org/10.1007/s12028-011-9605-9

28. Macdonald RL. Delayed neurological deterioration after subarachnoid haemorrhage. Nat Rev Neurol 2014; 10(1): 44-58. https://doi.org/10.1038/nrneurol.2013.246

29. Wessell A, Kole MJ, Badjatia N, et al. High compliance with scheduled nimodipine is associated with better outcome in aneurysmal subarachnoid hemorrhage patients cotreated with heparin infusion. Front Neurol 2017; 8: 268. https://doi.org/10.3389/fneur.2017.00268

30. Taccone FS. Vasodilation and neuroprotection: the magnesium saga in subarachnoid hemorrhage. Crit Care Med 2010; 38(5): 1382-4. https://doi.org/10.1097/CCM. 0b013e3181da4672

31. Wong GKC, Poon WS, Chan MTV, et al. Intravenous magnesium sulphate for aneurysmal subarachnoid hemorrhage (IMASH): a randomized, double-blinded, placebo-controlled, multicenter phase III trial. Stroke 2010; 41(5): 921-6. https://doi.org/10.1161/STROKEAHA. 109.571125

32. Kirkpatrick PJ, Turner CL, Smith C, et al. Simvastatin in aneurysmal subarachnoid haemorrhage (STASH): a multicentre randomised phase 3 trial. Lancet Neurol 2014; 13(7): 666-75. https://doi.org/10.1016/S14744422(14)70084-5

33. Macdonald RL. Clazosentan: an endothelin receptor antagonist for treatment of vasospasm after subarachnoid hemorrhage. Expert Opin Investig Drugs 2008; 17(11): 1761-7. https://doi.org/10.1517/13543784.17.11.1761

34. Macdonald RL, Higashida RT, Keller E, et al. Clazosentan, an endothelin receptor antagonist, in patients with aneurysmal subarachnoid haemorrhage undergoing surgical clipping: a randomised, double-blind, placebo-controlled phase 3 trial (CONSCIOUS-2). Lancet Neurol 2011; 10(7): 618-25. https://doi.org/10.1016/S14744422(11)70108-9

35. Mohney N, Williamson CA, Rothman E, et al. A propensity score analysis of the impact of dexamethasone use on delayed cerebral ischemia and poor functional outcomes after subarachnoid hemorrhage. World Neurosurg 2018; 109: e655-61. https://doi.org/10.1016/j.wneu.2017.10.051

36. Nassiri F, Ibrahim GM, Badhiwala JH, et al. A propensity score-matched study of the use of non-steroidal anti-inflammatory agents following aneurysmal subarachnoid hemorrhage. Neurocrit Care 2016; 25(3): 351-8. https://doi.org/ 10.1007/s12028-016-0266-6

37. Romano JG, Forteza AM, Concha M, et al. Detection of microemboli by transcranial Doppler ultrasonography in aneurysmal subarachnoid hemorrhage. Neurosurgery 2002; 50(5): 1026-31. https://doi.org/10.1227/00006123200205000-00016

38. Vergouwen MD, Vermeulen M, Coert BA, et al. Microthrombosis after aneurysmal subarachnoid hemorrhage: an additional explanation for delayed cerebral ischemia. J Cereb 
Blood Flow Metab 2008; 28(11): 1761-70. https://doi.org/ 10.1038/jcbfm.2008.74

39. Frontera JA, Provencio JJ, Sehba FA, et al. The role of platelet activation and inflammation in early brain injury following subarachnoid hemorrhage. Neurocrit Care 2017; 26(1): 48-57. https://doi.org/10.1007/s12028-016-0292-4

40. Di Vergouwen M, Vermeulen M, de Haan RJ, et al. Dihydropyridine calcium antagonists increase fibrinolytic activity: a systematic review. J Cereb Blood Flow Metab 2007; 27(7): 1293-308. https://doi.org/10.1038/sj.jcbfm.9600431

41. Dorhout Mees SM, van den Bergh WM, Algra A, et al. Antiplatelet therapy for aneurysmal subarachnoid haemorrhage. Cochrane Database Syst Rev 2007; (4): CD006184. https://doi.org/10.1002/14651858.CD006184.pub2

42. Athar MK, Levine JM. Treatment options for cerebral vasospasm in aneurysmal subarachnoid hemorrhage. Neurotherapeutics 2012; 9(1): 37-43. https://doi.org/ 10.1007/s13311-011-0098-1

J. Grigaitė, G. Rutkauskaitė, J. Ščerbak, L. Piliponis, D. Jatužis, J. Valaikienè

\section{LITERATURE REVIEW OF SPONTANEOUS SUBARACHNOID HAEMORRHAGE: TREATMENT MANAGEMENT AND PREVENTION (PART II)}

\section{Summary}

The most effective treatments for intracranial aneurysms are surgical clipping and endovascular coiling. Endovascular treatment has a lower risk of early death and complications, especially in the case of posterior circulation aneurysms, whereas the risk of recanalization and rupture of the aneurysm remains high there- fore long-term follow-up is needed. Meanwhile, the long-term benefits of clipping are very important for younger patients, and in some cases it is a first-line treatment option. Interventional treatment of aneurysms is recommended as early as feasible. To avoid complications, all patients with spontaneous subarachnoid hemorrhage are recommended to undergo transcranial dopplerography daily or every other day, as well as head computed tomography, computed tomography angiography (CTA), computed tomography perfusion or digital subtraction angiography on the day of hospitalization, 3-5 and 7-10 days. For the prevention of late cerebral ischemia, it is recommended to administer calcium channel blocker nimodipine and to maintain euvolemia. If cerebral vasospasm occurs, euvolemic-induced hypertension and, in some cases, endovascular treatment such as intra-arterial vasodilator therapy or/and angioplasty are recommended. The choice of treatment tactics for unruptured intracranial aneurysms depends on the natural course of the disease and the risk of rupture, which can be assessed using various scales. Following monitoring tactics, it is recommended to repeat CTA or magnetic resonance angiography (MRA) in 6 to 12 months after the aneurysm is detected to evaluate changes over time. CTA and MRA are also recommended for people with two or more family members with unruptured intracranial aneurysms or the diagnosis of SAH and other risk factors. Patients who are accidentally diagnosed with an unruptured aneurysm are recommended to quit smoking, have their blood pressure measured periodically, and avoid heavy weights.

Keywords: subarachnoid haemorrhage, intracranial aneurysm, endovascular coiling, surgical clipping, vasospasm, late cerebral ischaemia.

Gauta:

Priimta spaudai:

20210214 20210305 